\title{
Hogyan befolyásolja a kultúra az egészséget? II. rész: Táplálkozás, kultúra és egészség
}

\author{
How does culture affect health and well-being? \\ Part II: Nutrition, culture and health
}

A három részből álló cikksorozat további részei: "I. rész: Az egészség kulturális beágyazottsága", "Ill. rész: Környezet, kultúra és egészség"

Szerző: Nagy Barbara $\bowtie$

Országos Gyógyszerészeti és Élelmezés-egészségügyi Intézet

Beküldve: 2017.06.20.

doi: 10.24365/ef.v58i2.159

Kulcsszavak: egészség, kultúra, táplálkozás, redukcionizmus

Keywords: health, culture, nutrition, reductionism

\section{TÁPLÁLKOZÁS ÉS KULTÚRA}

Az étel egyfajta köteléket teremt az emberek között, pl. egy kapcsolat kezdetét gyakran egy közös étkezésre történő meghívás jelenti, esetleg újdonsült szomszédunkat egy csésze kávéra invitáljuk, vagy amikor egy potenciális partnert hívunk meg vacsorára. Ezzel szemben az étkezésre hívás hárítása ellenséges gesztus; a kapcsolat visszautasítását jelezheti.

Az étkezések, az ételek a mindennapi élet szerves részeként funkcionálnak, és rituálisan jelölik az utat a szertartásos ( $p l$. a menyasszonyi torta felvágása és elfogyasztása az esküvőkön) vagy hétköznapi (pl. közös családi vacsorák) életszakaszok mentén. Ez a nézőpont rámutat, hogyan teremtenek az ételek közös világszemléletet azok között, akik ugyanazon kultúrában élnek.

Elmondható tehát, hogy a közös étkezés minden társadalom egyik alapja, tulajdonképpen kultúra sem létezik étkezések nélkül.
Napjainkban az egyre nagyobb figyelmet kapó személyre szabott táplálkozás azonban úgy tekint az élelmiszerekre és ételekre, mint az egészségmegőrzés eszközeire. Az élelmiszerek és az egészség között egyfajta funkcionális kapcsolatot feltételez, ahol az ételek csupán másodlagos szerepet kapnak. A táplálkozás azonban ennél lényegesen nagyobb szerepet játszik az ember életében, kapcsolódik a társadalmi élethez, a kulturális értékekhez, az identitáshoz. ${ }^{1}$

Az étel és az étkezések kultúrában betöltött szerepét semmi sem jelzi jobban, minthogy a mediterrán diéta 2014-ben felkerült az UNESCO az emberiség szellemi kulturális örökségének reprezentatív listájára. A lista (komplex módon) úgy jellemzi a diétát, mint a terményeket, a betakarítást, a halászatot, az állattenyésztést, a feldolgozást, a főzést és különösen a megosztást és az élelmiszerek elfogyasztását magába foglaló készségek, tudás és hagyományok összességét. ${ }^{2,3} \mathrm{~A}$ mediterrán diéta hangsúlyozza még a vendégszeretet, a szomszédság, a kultúrák közötti párbeszéd és a kreativitás fontosságát, vala- 
mint felhívja a figyelmet a sokféleség tiszteletben tartására és arra, hogy az étkezés soha nem csak a táplálkozásról szól. Az ételek beszerzésének és elkészítésének feladata, továbbá az, ahogy megosztjuk az ételt, valamint ez által közvetített üzenetek mind alapvető fontosságúak annak meghatározásában, hogy pontosan mit is értünk étel és étkezés alatt. Az étkezés hatékonyan köt minket egy hasonló ízlésú és azonos szokásokkal rendelkező közösséghez. A táplálkozás tulajdonképpen az első viselkedési forma (már a megszületéstől kezdve), amelyen keresztül az ember megtanul létrehozni és fenntartani kapcsolatot másokkal, tehát igen nagy szociális jelentőséggel bír. ${ }^{4,5,6,7,8,9,10,11,12} \mathrm{Az}$ éhséggel, a jóllakottság érzésével, a mértéktelenséggel, az elégedettséggel, az önbizalommal kapcsolatos értékek mind kifejezésre jutnak a másokkal történő közös étkezések során és hatással vannak az élelmiszerválasztásra, az elfogyasztott ételek egészségre gyakorolt hatására. Éppen ezért, a táplálkozás-egészségügyet és a politikai döntéshozók azon törekvéseit, hogy támogassák vagy javítsák azt, a kultúra keretein belül is szükséges vizsgálni.

\section{VÁLTOZÓ IDŐK, VÁLTOZÓ SZOKÁSOK}

A migráció, az urbanizáció és a globalizáció folyamatai révén a hagyományos étkezési szokások megváltozhatnak, torzulhatnak és némely esetben akár teljesen el is túnhetnek. Ezeket a változásokat gyakran a modern élethez történő alkalmazkodás igényei hajtják, melyek hatására a korábban nagy jelentőséggel bíró közösségi étkezések eltűnhetnek, vagy időszakos ünnepekké, lakomákká alakulhatnak. Utóbbi esetben az sem ritka, hogy a hagyományos ételek fogyasztása ezen viszonylag ritka alkalmakkor túlzottá válik.

Ahogy az emberek távolodnak a régi szokásoktól, más életmódot, életritmust vesznek fel, egyre nagyobb valószínűséggel kezdik az étkezést csupán szükségszerűségként kezelni. Ezt bizonyítja, hogy egyre gyakoribbá válik az otthonon kívüli, vagy éppen a magányosan történő étkezés, hogy az élelmiszerek tápanyagtartalmára és biológiai értékére fókuszálunk, és arra hogy mit eszünk, de azzal nem törődünk, hogy miért eszünk és milyen többletjelentése lehet egy-egy étkezésnek. Ez a táplálkozási redukcionizmusnak (a táplálkozással kapcsolatos ál- lításokat egyszerű tényekre visszavezető gondolkodás) nevezett ideológia megkerüli az étel és az étkezések társadalmi jelentőségét, és helyette a tápanyagtartalmat és a táplálkozási ajánlásnak való megfelelést helyezi előtérbe. Az élelmiszerek értékének e tudományosabb irányú megítélése akár a kalóriák folyamatos számolásában, a makro- és mikrotápanyagok ajánlott napi beviteli értékének folyamatos nyomon követésében is megnyilvánulhat - nem terápiához kötötten is. Ugyan az egyes élelmiszerek tápanyag-összetételének ismerete és megértése fontos az egészséges táplálkozás szempontjából, de az ételeink ilyen jellegű tárgyiasítása nemcsak megfosztja azokat a történelmi és kulturális jelentőségüktől, de sokszor ellentmondást és zavart okoz abban a tekintetben, hogy miből is áll egy egészséges, megfelelően összeállított étrend. $13,14,15,16,17,18,19$

A táplálkozástudománnyal foglalkozó szakemberek és a politikai döntéshozók hajlamosak lehetnek arra, hogy erre a kérdésre további tápanyagbevitelt vizsgáló kutatással és a jobb választást támogató élelmiszer-címkézési követelményekkel válaszoljanak, ám a táplálkozási szokások nem mindig követik az elvárásokat. ${ }^{20}$ Egyre többen tudatában vannak ugyan a táplálkozási irányelveknek vagy éppen az élelmiszereken megjelenő információknak, azonban a mindennapokban az élelmiszerválasztást jelentősen befolyásolja az anyagi helyzet, az egyéni ízlés, az élelmiszerek elérhetősége, a családi szokások, valamint az élelmiszerbiztonsággal kapcsolatos meggyőződések. ${ }^{21,22,23}$ Más szóval a kizárólag biológiai és kémiai alapú egészség-üzenetek önmagukban nem képesek megváltoztatni az élelmiszer-választást, illetve csak akkor, ha az ajánlott iránymutatások követése az egyén számára nem okoz különösebb gondot, vagy már megszokottá vált. Még abban az esetben is, ha az élelmiszercímkén található információk teljes mértékben érthetők az egyén számára, a társadalmi tényezők akkor is nagyobb hatással lehetnek az egészségre, mint a kalóriák számolgatása.

Egy adott étrend, vagy a rendszeres testmozgás egészségre gyakorolt hatását felmérő kontrollált vizsgálatok során a résztvevőkről több esetben kiderült, hogy a program befejezése után nem tartják magukat a program során alkalmazott változtatá- 
sokhoz, tehát a csoport támogatásának megszűnésével csökken az elköteleződés. ${ }^{24,25,26}$

Az egyéni értékrend és más kulturális tényezők, mint például az iskolázottság, valamint a jövedelem, szintén fontos szerepet játszanak az emberek egészség-üzenetekre adott rövid és hosszú távú válaszaiban. Ezért a táplálkozás kulturális oldalról való megközelítése nemcsak annak feltárásához szükséges, hogy az egyén viselkedését miként befolyásolják bizonyos tényezők, hanem megfelelő eszköz lehet az esetlegesen észlelt akadályok leküzdéséhez, elkerüléséhez, továbbá segíthet kialakítani az egészséget támogató választásokkal és az egészséges életmóddal kapcsolatos közösségi identitás érzését.

\section{AHOL A KULTÚRA ÉS A TUDOMÁNY TALÁLKOZIK}

A brazil Egészségügyi Minisztérium táplálkozási irányelvei kiváló példaként szolgálnak a kulturálisan megalapozott megközelítésre. ${ }^{27} \mathrm{Az}$ irányelvek tápanyag alapú helyett élelmiszeralapú megközelítést alkalmaznak, gondosan őrzik a lakosság körében fenntarthatóan előállított termékeket és kultúrájukba megfelelően illeszkedő élelmiszerekhez való hozzáférés jogát. Az iránymutatások arra a felismerésre épülnek, hogy az adott étrendnek egészségre gyakorolt hatása nagymértékben összefügg a társadalmi és kulturális környezettel, melyben az ételek és az étkezések olyan plusz jelentéstartalommal telnek meg, mint például a növénytermesztés gyakorlata, az ételkészítés folyamata, a közös étkezések és az ételek élvezete. A brazil modell egyértelmúen támogatja azon nézetet, hogy az egészséges táplálkozás sokkal több, mint a megfelelő mennyiségú kalóriabevitel. A mediterrán étkezéshez hasonlóan a társalgás, az összetartozás és az emlékek teremtése mind fontos összetevői az igazán tápláló, kiegyensúlyozott étkezéseknek.

A tápanyagszámítás gyakorlatának elterjedése kétségtelenül hozzájárult a közvélemény tudatosságának növeléséhez és a lakossági szintű beavatkozások erősítéséhez. Azonban egy ilyen alapokon nyugvó kizárólagos megközelítés elhomályosítja azokat a tapasztalatokat, azt a hétköznapi környezetet, melyben a táplálkozásunkra vonatkozó útmutatások értelmet nyernek, alkalmazhatóvá válnak, és melynek segítségével változtathatunk berögzült egészségtelen szokásainkon.

A táplálkozási redukcionizmus tehát elsősorban a személyes felelősséggel kapcsolatos értékeket hangsúlyozza - az ételeknek a társadalmi kapcsolatokban, gondoskodásban és a szokások kialakításában betöltött szerepével szemben - ezzel a közösségi kultúráról az egyéni cselekedetekre helyezve a hangsúlyt. Ez a személet napjainkra meghatározó erővé vált, amely nem csak az ételekhez füződő viszonyunkat változtatta meg, de a politikai döntéshozatalban is jelentős szerepet tölt be.

Mindez rávilágít arra is, hogy a kulturális tényezők valójában rendkívül erős szerepét a táplálkozásfüggő krónikus nem fertőző megbetegedések kialakulásában még mindig nem veszik kellően figyelembe, és a politikai döntéshozók is csak most kezdik megérteni, miként és milyen mértékben változtathatják meg a kulturális szempontok az egészségtelen táplálkozási szokásokat. 15,20

\section{A PIAC KRITIKUS SZEREPE}

A feldolgozott élelmiszerek forgalomba hozatalára vonatkozó szabályok biztosítása mellett a táplálkozási redukcionizmus ideológiája kulcsszerepet játszik az élelmiszertermelésben és -fogyasztásban, valamint az árukereskedelemben is. ${ }^{28} \mathrm{~A}$ redukcionista szemléletre jellemző hogy egyszerüsített, rövid információk használatával az élelmiszeripari vállalatok képesek a termékeiket rendkívül intenzíven reklámozni, olyan állításokat használva, amelyek megkapóak, ám valóságtartalmuk nem mindig ellenőrizhető. ${ }^{13,14,15} \mathrm{Nem}$ csoda, hogy az ilyen reklámtevékenység mellett, a tradicionális élelmiszer-kultúrák gyorsan átalakultak, lecserélődtek vagy idejétmúlttá váltak az emberek szemében. ${ }^{29,30} \mathrm{Az}$ egyre gyorsabban fejlődő iparosodás drámaian megváltoztatta az étkezés kulturális megközelítését: az élelmiszerek napjainkra nem képviselnek közös értéket, a családi étkezéseket pedig egyre inkább helyettesítik az előrecsomagolt, fogyasztásra (és túlfogyasztásra) szánt élelmiszerek, melyek szinte bárhol és bármikor beszerezhetők. Ezzel szemben a WHO tanulmánya szerint a friss, vagy minimálisan feldolgozott élelmiszerek gyakran nehezebben elérhe- 
tőek és drágábbak, nem beszélve arról, hogy a feldolgozásukhoz, elkészítésükhöz szükséges készségek is eltünőben vannak.

Az iparosodásnak, valamint a modernizáció és urbanizáció hatására változó fogyasztói szokásoknak nagy hatása volt a gazdálkodási kultúrákra világszerte, arra kényszerítve a termelőket, hogy az ökológiailag megfelelő és hagyományos termesztési módok helyett szálljanak be a globális gazdasági versenybe. ${ }^{31} \mathrm{Az}$ ilyen gyors változás mind a biológiai, mind a kulináris sokféleséget fenyegeti: ahol korábban a helyi gazdák egyszerre több száz, akár több ezer különböző terményt szolgáltattak a helyi és regionális közösségek számára, most az ipari gazdaságok csak néhány magas hozamú, azonnali exportra szánt növényt termesztenek.

Az ilyen mély változások megkövetelik a politikai döntéshozóktól, hogy kritikusan szemléljék az egész világon egyre jobban reklámozott iparosodott élelmiszer-kultúrákat, és azt hogy mi tekinthető bizonyítottan az egészség megőrzését támogató élelmiszernek. ${ }^{32}$

\section{AJÁNLÁSOK}

A táplálkozás-egészségügyi programokkal foglalkozó szakemberek számára az alábbi szakpolitikai lehetőségeket ajánlott figyelembe venni az Egészségügyi Világszervezet szerint.

1. Támogassák a kultúra táplálkozásban betöltött szerepét alátámasztó további kutatások lebonyolítását!

2. Segítsék annak felismerését, hogy az élelmiszerek kiválasztásának, előkészítésének és a közös étkezéseknek a kulturális háttere erősítheti a lakosság egészségét és jólétét, és ezeket a társa- dalmi tényezőket a politika szintjén is szükséges támogatni!

3. Vonják be a helyi közösségeket az olyan helyes élelmiszer-választást előmozdító stratégiák kialakításába, amelyek kulturális gyakorlatokra épülnek és segítik az egészség és a jól-lét kiterjesztését!

4. Biztosítsák, hogy az egészséges táplálkozással kapcsolatos üzenetek igazodjanak ahhoz a környezethez, melyben az emberek értelmezik őket, és amelyben elvárjuk, hogy pozitív irányban változtassanak viselkedésükön!

5. A különböző perspektívák (pl. történelmi, társadalmi, etikai) figyelembevételével működjenek együtt az élelmiszeriparral!

\section{A JÖVŐ KÉRDÉSE}

Az étel és étkezés létfontosságú mind az emberi szervezet számára, mind pedig a társadalmi kapcsolatok építéséhez és fenntartásához. Mivel az élelmiszerek, ételek és a táplálkozás biológiai és kulturális dimenziói elválaszthatatlanok, a személyre szabott táplálkozás esetében is a multidiszciplináris megközelítés szükséges. Az irányelveinek kidolgozásakor szintén figyelembe kell venni az ételek szerepét a mindennapi élet rendszerében - a társadalmi kapcsolatokban, a személyes identitásban.

Az ételek mind tudományos, mind biológiai és kulturális szempontú megközelítése indokolt, de a mögöttük álló érvelés különböző. Ígéretes tudományos megközelítésként a személyre szabott táplálkozás sikeressége a jövőben valószínúleg attól függ, hogy képes-e integrálni a tudományos megközelítést az ételek mindennapi kulturális, érzelmi, érzéki és etikai értelmével. ${ }^{1}$

\section{HIVATKOZÁSOK}

\footnotetext{
${ }^{1}$ Nordström, K., Coff, C., Jönsson, H., Nordenfelt, L., \& Görman, U. (2013). Food and health: individual, cultural, or scientific matters? Genes \& nutrition, 8(4), 357-363.. Paris: UNESCO; 2014

${ }^{2}$ Mediterranean diet [website]. Paris: UNESCO; 2014 (http://www.unesco.org/culture/ich/en/RL/mediterranean-diet00884, Elérve: 2017. 06. 13)

${ }^{3}$ Cultural Contexts of Health and Well-being. Policy brief, No. 1, Culture matters: using a cultural contexts of health approach to enhance policy-making. World Health Organization, Regional Office for Europe, 2017

${ }^{4}$ Coleman L, editor. Food: ethnographic encounters. London: Bloomsbury Academic; 2011.
} 
${ }^{5}$ Goody J. Cooking, cuisine and class. A study in comparative sociology. Cambridge: University of Cambridge Press; 1982.

${ }^{6}$ Kraemer FB, Gracia Arnaiz M. Feed or nourish in a "popular restaurant" in Spain: reflections on commensality. Demetra 2015;10(3):455-66. doi:10.12957/demetra.2015.16173.

${ }^{7}$ Mintz S. Food and its relationship to concepts of power. In: McMichael P (editor). Food and agrarian orders in the worldeconomy.London: Praeger; 1995 (3-13).

8 Fischler C. L’homnivore. Paris: Odile Jacob; 1990 (in French).

${ }^{9}$ Ritter M, Frisbe D. Sociology of the meal. In: Simmel on culture: selected writings. London: Sage Publications; 2000:130-6.

${ }^{10}$ DeVault ML. Feeding the family. The social organization of caring as gendered work. Chicago: University of Chicago Press; 1991.

${ }^{11}$ Murcott A. "It's a pleasure to cook for him": food, mealtimes and gender in some South Wales households. In: Garmanikow E, Morgan D, Purvis J, Taylorson D, editors. The public and the private. London: Heinemann Educational Books; 1983 (78-90).

${ }^{12}$ Fischler C. Commensality, society and culture. Social Science Information 2011;50(3-4):528-48. doi:10.1177/0539018411413963.

${ }^{13}$ Scrinis G. On the ideology of nutritionism. Gastronomica 2008;8(1):39-48. doi:10.1525/gfc.2008.8.1.39.

${ }^{14}$ Scrinis G. Nutritionism: the science and politics of dietary advice. New York: Columbia University Press; 2013.

${ }^{15}$ Scrinis G. Reformulation, fortification and functionalization: Big Food corporations' nutritional engineering and marketing strategies. The Journal of Peasant Studies 2015;43(1):17-37. doi:10. 1080/03066150.2015.1101455.

16 Yates-Doerr E. The opacity of reduction, nutritional blackboxing and the meanings of nourishment. Food, Culture and Society 2012:15(2)293-313. doi:10.2752/175174412x13233545145381.

${ }^{17}$ Sanabria E. Circulating ignorance: complexity and agnogenesis in the obesity "epidemic". Cultural Anthropology 2016;31(1)131-58. doi:10.14506/ca31.1.07.

18 Bouman LI, te Molder H, Koelen MM, van Woerkum CMJ. I eat healthfully but I am not a freak. Consumers' everyday life perspective on healthy eating. Appetite 2009;53(3):390-8. doi:10.1016/j.appet.2009.08.005.

${ }^{19}$ Crawford RA. A cultural account of "health": control, release, and the social body. In: McKinlay JB, editor. Issues in the political economy of health care. New York: Tavistock Publications; 1984.

${ }^{20}$ Sanabria E, Yates-Doerr E. Alimentary uncertainties: from contested evidence to policy. Biosocieties 2015;10(2):11724. doi:10.1057/biosoc.2015.17.

${ }^{21}$ Fischer E, Benson P. Broccoli and Desire. Palo Alto: Stanford University Press; 2006. 30.

${ }^{22}$ Margetts B, Martinez J, Saba A, Holm L, Kearney M, Moles A. Definitions of "healthy" eating: a pan-EU survey of consumer attitudes to food, nutrition and health. Eur J Clin Nutr.1997;51:23-9.

${ }^{23}$ Holm L. Mad og sundhed i hverdagen [Food and health in everyday life]. In: Holm L, Kristensen ST, editors. Mad, mennesker og måltider - samfundsvidenskabelige perspektiver [Food, people and meals - perspectives from social sciences]. Copenhagen: Munksgaard; 2012:301-16

${ }^{24}$ Holm L. Cultural and social acceptability of a healthy diet. Eur J Clinl Nutr. 1993;47(8)592-9.

${ }^{25}$ Micheelsen A, Havn L, Poulsen SK, Larsen TM, Holm L. The acceptability of the New Nordic Diet by participants in a controlled six-month dietary intervention. Food Quality and Preference 2014;36:20-6.

doi:10.1016/j.foodqual.2014.02.003.

${ }^{26}$ Nielsen A, Korzen S, Holm L. Inverting the food pyramid? Social and cultural acceptability of Walter Willett's dietary recommendations among people with weight concerns. Appetite 2008;51(1):178-86. doi:10.1016/j.appet.2008.02.011.

27 Dietary guidelines for the Brazilian population. Brazillia: Ministry of Health of Brazil; 2015

(http://bvsms.saude.gov.br/bvs/publicacoes/dietary guidelines brazilian population.pdf (Elérve: 2017.06.13)

${ }^{28}$ Stuckler D, Nestle M. Big Food, food systems, and global health. PLOS Med. 2012;9(6)e1001242.

doi:10.1371/journal.pmed.1001242.

${ }^{29}$ Patel RC. Food sovereignty: power, gender, and the right to food. PLOS Med. 2012;9(6)e1001223.

doi:10.1371/journal.pmed.1001223.

30 Monteiro CA, Cannon G. The impact of transnational "Big Food" companies on the south: a view from Brazil. PLOS Med. 2012;9(7):e1001252. doi:10.1371/journal.pmed.1001252.

${ }^{31}$ Pratt J. The rationality of rural life: economic and cultural change in Tuscany. Chur: Harwood Academic Publishers; 1994.

32 Yates-Doerr E. The weight of obesity: hunger and global health in postwar Guatemala. Berkeley: University of California Press; 2015. 